\title{
The New Aid White Paper: Four Views
}

Reviews of Ministry of Overseas Development, Overseas Development: The Changing Emphasis in British Aid Policies: More Help for the Poorect, HMSO, October 1975, 95p.

... we and other aid donors are now adapting our aid policies to give more help to the poorest countries and the poorest people within these countries...

\section{Suitably Modest}

\section{Charles Elliott}

The main proposals of this White Paper are well known, at least in broad outline, to most development specialists. Taken as a whole they constitute the most determined and far-reaching attempt to change the direction, composition and nature of British aid since the days of Andrew Cohen and the DTC. They stem not only from Judith Hart's political leadership but more fundamentally from the professional concern of the last six years for the alleged failure of development in general and aid in particular to raise the level of living of the poorest of the poor.

The White Paper is suitably modest-some may think exaggeratedly so-about how much aid donors can in fact do to ensure that benefits accrue permanently to the poorest. Depending upon where one stands in the "Culture of Poverty" debate, one will recognise in that modesty either an acknowledgment of the structural factors that consistently reinforce the poverty of the poor or a more 'vulgar' realisation that no aid programme can prevent the switching of domestic resources or plug the gap between propaganda and reality. It would be a rash or optimistic reader who chose the first interpretation, for there is little evidence in the rest of the document that the structures and mechanisms of the reinforcement of poverty have yet been much recognised in ODM. While it would be unfair to attribute to the White Paper's authors the same kind of 'resource aggregation' naivete that marked much early (and current) World Bank 'poverty planning' (ghastly phrase), it is nonetheless true that the analysis of the causes of poverty implicit (and only occasionally explicit) in the White Paper veers nearer to the 'shortage of resources' end of the ideological spectrum than the 'exploitative relationships' end.

To expect otherwise would no doubt be fanciful. It is nonetheless disappointing that, even within its own circumscribed ideological limits, the White Paper shows a bureaucratic rigidity that bodes ill for the rapid or thoroughgoing implementation of the new policy. Consider this paragraph on the crucial issue of local costs-an issue, incidentally, that has been consistently hammered in the poverty-aid literature and by the Select Committee on Overseas Development in at least two Reports to the House of Commons:

We are ready to consider allowing in exceptional cases a limited part of our financial aid to meet local costs of individual projects. We take account of a number of factors. The most important is the development case. This will in turn depend on such things as the availability to the recipient country of domestic resources and free foreign exchange, and the efforts made to improve the mobilisation of those resources.

What, one wonders, will turn out to be an 'exceptional case'? And why does it need to be exceptional anyway? If the arguments turn out to be the tired trio of the British balance of payments, local commitment to the projects as manifested by the mobilisation of domestic resources and the avoidance of recurrent commitments, we need to treat the new orientation of the aid programme with, at least, considerable reserve.

There are two further reasons for gentle scepticism. The first is the hoary issue of absorptive capacity. Of course the White Paper recognises this and promises "more technical assistance to identify, formulate and implement projects and programmes" (p.10). At worst, this could be an invitation to World Bankish insensitivity, with expatriate experts 'identifying' the needs, priorities and aspirations of deprived people, with never a thought given to involving them in the slow, frustrating and sometimes conflict-laden business of deciding their own preferences and requirements. This is not necessarily to argue that only 'bottom-up' programmes can have an immediate and lasting impact on poverty; it is to suggest that under pressure to make the new policy stick, aid officials can all too easily ignore the lessons that social (if not economic) planners are beginning to learn from 20 years of disappointment. 
The second reason for gentle scepticism is that it is one thing to produce a White Paper which makes all (or at least some) of the right noises; it is quite another to make that policy stick. One wonders how the Minister views aid to Greece and Portugal in a post-White Paper era? True, there are very poor people in those countries, but that is the nub. By directing its priorities to the poorest countries (and those among them with the worst growth prospects), the White Paper opts out of the relative/absolute poverty debate altogether. For it assumes that poverty is defined by scarcity rather than by inequality. True, it can be argued that as far as aid is concerned, this is the only definition that makes operational sense. The reader must judge for himself whether that is a valid argument. If it is, this White Paper is not only on aid to poverty: it is on the poverty of aid.

.. The improvement in the living standards of the world's poor is one of the major challenges of our time...

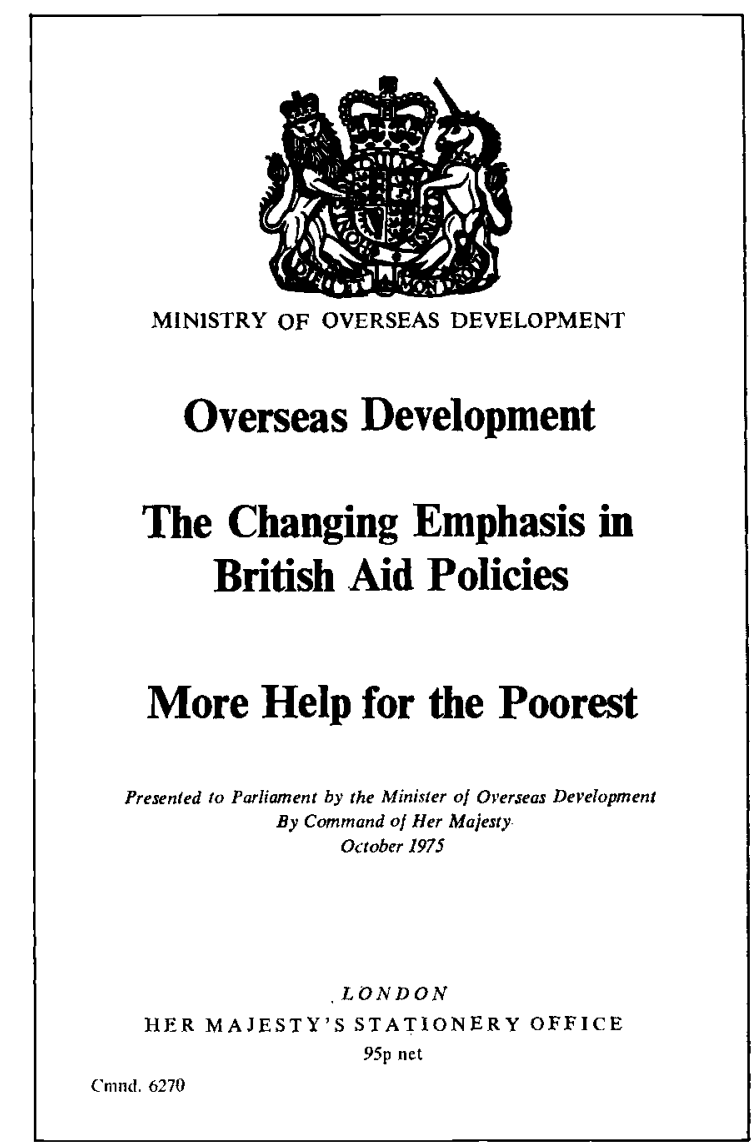

. . more should be done to ensure that a higher proportion of British aid should directly benefit not only the poorest countries but the poorest people in those countries ...

Policies for the Poor and Hungry

T. W. Gee

The international economic analysis in the ODM's second White Paper The work in hand (Cmnd. 3180-1967) concluded with a prophetic sentence. Many developing countries, it suggested, especially producers of petroleum or metal ores, would continue to receive sufficient foreign exchange, but an increasing number were likely to find their growth rate constrained by shortage of it.

The third White Paper More Help for Ine Poorest (Cmnd. 6270-1975) identifies the sharp oil price rise as critical for developing countries, with many now concerned with survival rather than development, because of serious deterioration in their terms of trade.

There is little else which spans the eight year gap between these two White Papers. Cmnd. 3180 was written in days of hope at the beginning of the Second Development Decade and echoes memories of the closing period of colonial rule. It opened with a cautiously optimistic global view of growth in production (and people). It was written when ODM was excited with problem-solving and fired by the leadership, commitment, and enthusiasm of Andrew Cohen (who died in the following year).

Today there is a more sombre mood. The opening summary paragraph of the 1976 Select Committee Report on Overseas Development on the world food crisis states that if the changes proposed are not put into effect by all donors, millions more people throughout the world will die. The expert evidence in the ensuing 400 pages reveals that the task of feeding the world's people is truly formidable.

There has been change in another respect, too. Today, opportunities for effective direct intervention by Britain are much fewer, particularly in the key rural areas, and the number of Britishers directly employed by overseas governments, universities, and other institutions continues to decline. As Julius Nyerere realised early in the last decade, the impetus for development must come from within. The Permanent Secretary told the Select Committee, in the context of directing aid to the poorest people, of today's need to work within the commitments and plans of recipient countries, and that nothing could be 
done where they lacked the political will or capacity to act. Accusations of unwarranted interference in internal matters are understandable, when the critical issues are redistribution of income and unemployment. Informed comment on such questions embarrasses political leaders, particularly when it draws attention to the widening gulf between the urban elites and rural peasants, and policies which import inappropriate Western industrial technologies. The increasing demand for a fundamental restructuring of international trade has attractions as an alternative method for redistribution between nations, but as with aid for the poorest, internal policies determine the haves and the have-nots, and whether any increase in prices of primary products actually benefit the producers.

More Help for the Poorest recognises all these limits imposed on donors that want to expand rural development programmes. The wishes of recipients must be respected and so must their sensitivity to prescriptive advice on policy matters at the heart of the internal political process in all countries. Increasingly, acceptable expertise must be limited to the provision of know-how, and technique. This becomes the donor's dilemmahow to offer but not to prescribe the right medicine: to make available what is best for the recipient, to be sure that it is his choice and that he chooses right. Providing more aid to the poorest is neatly summed up in Cmnd. 3180 as "easier said than done". The hope seems to be that consultation, conferences and discussion will lead to successful cooperation between donor and recipient in choosing the right projects, but can this hope be fulfilled in respect of policies that seek to penetrate such sensitive areas? There are attractions in using voluntary and multi-lateral channels for these new programmes, but international experts tend to be anodyne, bureaucratic, expensive, and remote (and oddly inappropriate figures to handle poverty-focused planning).

The doubts raised by the White Paper lead one to speculate about what can and should be done to help one another in a world of many new nations asserting their independence. The concluding chapter of Cmnd. 6270 pays lip service to the need to make some reference to trade policies ('incomplete without some mention'). This raises a wide set of issues not tackled in ODM's departmental White Paper on Aid and effectively postponed once again in Britain's recent 'talk about talks' at UNCTAD IV. Another longer run concern is the fundamental question of educating our own people in Britain to think internationally, because the way we set about this process must be a determinant of Britain's future role in
... the Government has decided, that there should be an increasing emphasis on aid to the poorest countries...

the world and whether we shall continue to be influential in the new situation now taking shape in the remaining part of this century. Trade, and development education, (and overseas tuition fees?) are examples of areas where we can act to promote the ends with which the White Paper is concerned without facing the difficulties of aid programmes; they can be settled in our own front yard'. Departmentalism in Whitehall prevents their being seen in that context.

In the third quarter of this century the world has shifted from an era of imperial dependency towards one characterised by strong nationalistic independence. Hopefully in this last quarter we shall explore areas of mutual cooperation-of international interdependence-where north and south can work together. The technology to eliminate poverty exists and we must together put it into use. This is the challenge now before us, identified by the latest White Paper.

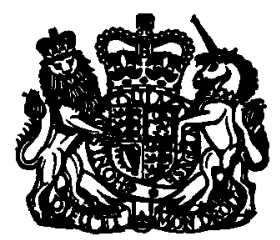

MINISTRY OF OVERSEAS DEVELOPMENT

\section{Overseas Development}

\section{The Changing Emphasis in British Aid Policies}

\section{More Help for the Poorest}

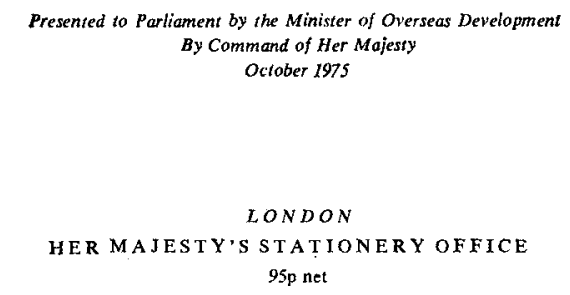

Comnd. 6270 
... the character of the political, social and economic power structure in each country conditions the power of governments to ensure a more equitable distribution of the benefits of growth...

\section{New Directions?}

\section{Ashok Mitra}

The mythology of external aid is one of variegated splendour. Leave out at one end the fire-brand radical who would not touch foreign money with the lengthiest barge pole, and at the other the true-blue colonialist who still awaits, in the manner of Seventh Day Adventists, for the second coming of a Robert Clive or a Gordon Pasha. The spectrum in between would still cover theists of innumerable descriptions. Amongst the recipients, there are those who regard external assistance as a prerogative-an expiation on the part of the imperialist scoundrels for all the exploitation they had indulged in in the course of the past three centuries. There are the 'structuralists', who rationalize aid as compensation for unjust injuries inflicted by shifts in terms-of-trade. Yet others accept it, without flinching, as hush money, or demand it as straightforward blackmail. On the side of donors are those who are bent on saving the world from the clutches of a heathen ideology, others who want the world power balance to be modestly tilted on their side, or those who are keen to ensure the demand for their (often obsolete and over-priced) goods and services by dangling aid funds and thus kill two birds with one stone. In the final category are the wide array of liberals, econometricians and Quakers not excluding, who genuinely believe in the proposition that global welfare can be added to if, at the margin, some resources are transferred from the relatively rich to the relatively poor nations.

Not surprisingly, what has emerged as a practising art in the post-World War II period is a hotchpotch. As the international political climate has changed, so have nuances in the craft of aidgiving-cum-receiving. But for each governmentand international organization - its particularised myth has constituted the staple of public relations: we are offering (accepting) aid to further this or that noble objective. The reality underlying the myth has been, in nearly all cases, substantially different. National self-interest has ruled supreme. Even the jingoes in the developing world, who elevate foreign assistance to the level of a moral right, have no way of enforcing their claim: if the United States, for instance, refuses to cough up, they cannot invade that country with their armed forces, or threaten it with nuclear annihilation. A government has decided to dole out credit or grants to another government pretty much in the manner it has felt would maximise its interests; it has, on its own, decided upon the quantity to be disbursed as also the countries where the aid ought to flow. Occasional preaching on the part of international bodies has had little impact, if any at all, on the magnitude and pattern of assistance: it is only when what an outside agency suggested coincided with a government's own predilections that there has been a convergence of international preaching and national practice. If Salvador Allende failed to obtain any funds from the United States, it was not just because the World Bank too was not disbursing any money to him; the US had its own reasons, and perhaps, given the weightage exercised by that nation, the causality was the other way round. Similarly, if the floodgates of American munificence are now threatening to overwhelm Admiral Pinochet's regime, and the World Bank too is discovering reasons why Chile has once more become 'bankable', the underlying factors have nothing to do with any consistent, symmetrical philosophy of philanthropy; those who decide to give money to others do so for their own reasons. As Mae West once indicated in a slightly different context: intrinsic goodness has nothing to do with it.

It is equally necessary to dispel certain other notions in this area. The Ministry of Overseas Development's latest White Paper on foreign aid reads very well; for undergraduate students called upon to prepare tutorial essays on the shifting cultural norms affecting external assistance, this would prove to be an excellent primer. The document is frightfully à la mode. The United Nations has wakened up to the fact in the decade of the 1970 s that, amongst its members, some are 'the least developed'; Robert McNamara in the World Bank has stumbled upon the parallel fact that, in developing countries as elsewhere, there is such a phenomenon as incomes being unequally distributed between groups and sections. It is never polite to ask too many questions; why this belated acquisition of knowledge should therefore remain beyond the realm of speculation. The poor having been discovered, the call has gone out: henceforth, the emphasis in policy should be on the uplift of the most deprived within each nation. Individual governments too have taken up the cue: slogans, howsoever full-throated, break no bones. As far as international organizations and foreign governments are concerned, there is no reason to think that they are anything but wellmeaning. Besides, some of these external agencies 
may be displaying a species of perspicacity in urging national governments to concentrate on the problems of the poorest, for, in case nothing gets done, a bloody revolution could well be round the corner. Such revolutions may change the global balance of power in a way which may not be relished by a body such as the World Bank, so it may not be all altruism. Nonetheless, there may also be an honest core of compassion for the poorest.

The British government White Paper toes this benevolent line. Echoing recent $U N$ and World Bank documents, it refers to the fact that efforts over the past quarter of a century notwithstanding many developing nations continue to be afflicted by a chronic set of problems : large-scale unemployment and under-employment, rapid growth of population, lagging food supply, and increasing polarization between a small, affluent sector and the overwhelming majority condemned to remain at the barest level of living. The recent energy crisis, in addition, has blighted the growth prospects of many of these countries. Accordingly, the broad strategy of British development aid is seen as consisting of (a) an increasing stress on providing aid to the poorest countries, particularly those 'most seriously affected by the rise in the price of oil and other commodities', and (b) programmes 'orientated towards the poorest groups within these countries, and especially to rural development'. Different chapters in the White Paper explain how this two-pronged strategy is going to be worked out. Countries with per capita annual incomes of less than $\$ 200$ are designated as the poorest; it is mentioned that, since mid-1975, aid commitments to these countries are being made on a straightforward grant basis. It would be possible to accord the most effective help, the White Paper implies, 'to those governments which see the need for, and are trying to implement, policies and programmes directly affecting poverty, employment and income distribution'. Since most of the poorest in the least developed countries are concentrated in rural areas, mention is made of the desirability of an integrated approach 'with attention paid to such matters as rural roads, water control, credit facilities, marketing machinery, elementary education and rural health facilities'. The broad framework of policy thus laid down, other chapters refer to detailed issues pertaining to housing, urban development, population control (with a full-fledged recognition of the new wisdom that .. . population aid is not merely a matter of family planning programmes, since a rise in living standards appears to be a necessary pre-requisite'), emergency assistance for food, fertilizer and disaster relief, etc. The rest of the chapters, dealing mostly with the problem of co-ordination with international bodies, support the by-now standard quasi-liberal prescriptions, such as support for the World Bank's 'third window' and the IMF's Oil Facility; there is also reference to the need of persuading the oil-rich countries to do more for the poorest nations. The intent to co-operate with the UN and its specialised agencies is reiterated, the Lomé convention is hailed, an oblique point is made that perhaps the EEC could do a little bit more 'for the most populous and poorest states in the developing world'. Finally, there is mention of the on-going trade and commodity control negotiations which should take account of the needs of the poorest developing country producers'. Predictably, the British initiative at Kingston on the commodities question receives laudatory reference.

In short, all the proper noises, all the proper nuances, nobody can fault this document on the ground that it fails to keep up with the developmental assistance Joneses. The basic issue is however not even touched upon. The document proceeds on the presumption that foreign donors are at liberty to choose those upon whom to bequeath their favours within a developing country. There is a certain apparent innocence in the way prescriptions are doled out: we, the outsiders, resolve unto ourselves that, from now on, when we go out to a poor land, we will assist only the most wretched ones, we will concentrate on providing basic education, health facilities, credit, etc., for the latter, we will tell the government of the country to make the necessary ancillary arrangements so that this decision of ours could be efficiently implemented. But these governments in the recipient nations are sovereign entities; they may not do your bidding.

Just as no poor nation can hope to extract specified quantities of assistance from this or that rich nation for this or that purpose merely by asking, similarly no would-be donor nation is in a position to insist, or ensure, that the aid she is providing is to be earmarked for this or that group. This is not, you know, how it is done in the real world. In each developing land, the poorest have reached their present plight because the decks have been consistently loaded against them by the ruling groups. It is not unnatural for the entrenched elements to take care that the distribution of income and assets remains skewed in favour of themselves-and their near and dear ones-in the countryside as well as in the urban areas, whatever the current fashion in aid-giving. Provided they are not particularly worried about either the lessons of history or the occasional 
forebodings of a Robert McNamara (particularly a McNamara presumably recovering from the trauma of Vietnam), they will feel scarcely enthusiastic towards exotic programmes for ameliorating the conditions of the poorest. The ruling groups may seemingly go along with projects which, on the face of it, intend to shower benefits on the most deprived and exploited ones, and receive resources from abroad on the basis of an implicit commitment to spend them on such projects. But what they do with the money remains basically their own business. The practice of end-use inspection for bilateral aid is, for all practical purposes, a non-starter; there are sensitive issues of sovereignty involved; apart from some polite exchange of pious wishes, a donor government can do little to ensure that the funds do in fact reach those for whom they were intended in the first place. This would be especially so in respect of rural projects: a foreigner, barging in to discover for himself whether the funds are going to the right people or are being siphoned off by the minister's son-inlaw or the ruling party's local henchmen, will be in danger of receiving short shrift. And realpolitik being what it is, few foreign governments would have the courage to cut off priorly committed aid to a country on the ground that the poorest are not benefiting from it.

There is, besides, that other essential truth which holds in all seasons: more often than not, the marginal unit of external assistance finances not the economically most sensible or the socially most desirable project, but the one which was at the top of the government's own waiting list. This is a fact of life which no amount of wellintentioned essay-writing can unsettle.

Ring-a-ring-a-roses, a pocketful of poses. But, whatever the current jargon of obfuscation, aid-receiving between nations would always be a matter of optimisation of mutual interests of the governments involved; serving the cause of the poor-sorry, the poorest-has per se nothing to do with it. So please don't be surprised if, despite this White Paper, at the end of another decade, the net impact of British assistance, original intentions notwithstanding, is adjudged to having contributed to a further aggravation of social and economic inequalities in India, Kenya or the Bahamas.

... There is an important difference between concentrating on increased agricultural production per se and increased agricultural production through the medium of rural development. The latter should involve an improvement of the standard of life of the rural population...
. . projects and programmes should be designed to ensure as far as possible that the employment and incomes of the poorest groups grow at an acceptable rate without undue sacrifice in the growth of production...

\section{What is Said and What Left Unsaid}

\section{Robert Cassen}

If the International Monetary Fund were to stipulate that future loans to the United Kingdom should be used as far as possible to mitigate poverty in Britain, the intelligent British citizen would be surprised and somewhat irritated: surprised because that's not the sort of policy we expect from the IMF; and irritated because-well, who are they to tell us what to do? The new White Paper on aid goes out of its way to respect the sensitivities of potential recipient governments; but members of these governments, whatever they may say in public, might well express irritation in private at some of these 'new emphases'. (Presumably no government of a poor country would say in public that the eradication of poverty was not a high priority.) My assessment of the new emphases starts from a view of the motives for aid giving: without the political and commercial interest of the aid 'donors', there would be no aid to speak of-but without the altruistic motives of much of the public opinion which supports aid, the volume of it would be much smaller than it is. Many people (myself included) wish to see the mitigation of poverty not because there will otherwise be revolutions or troubles that threaten our own way of life, but because poverty is obnoxious in itself, and the desirability of its removal one of the nearest things to a moral certainty that we know of in a morally perplexing world. That aid can contribute to the mitigation of poverty $I$ have less doubts about than its many critics of the right and the left (Ashok Mitra included). My difficulty with the White Paper is that, because it stems from the Ministry of Overseas Development, it almost of necessity stops you from perceiving the murk of many British policies-or lack of policies - towards the Third World because of the dazzling light of its own virtue.

Since aid is going to continue, it seems a good thing to me that these new emphases are penetrating Whitehall. It seems right that aid should go mainly to those who most need it, provided that they will use it well. It also seems right that aid should be directed towards the most povertyafflicted sections of the populations of recipient countries, insofar as it can be. The actual changes 
in Britain's aid programme that will result from the rethinking of policy will in fact be very modest and very slow. A high proportion of our aid already goes to the poorest countries ( 70 per cent of new commitments in 1974), and 'various considerations will require the continuance of some aid flows to not-quite-so-poor countries.' When it comes to poverty within countries, the main instrument of policy is more aid for rural development: but all the White Paper actually suggests doing about that is regrouping its staff into a new Rural Development Department, and trying harder to promote requests for appropriate rural projects.

This latter issue is a weak point in the White Paper, to my mind. It may be hard to 'do more' in the rural development field. But it does not follow from the fact that $x$ is of high priority, that more aid should flow into $x$. Britain has little comparative advantage in fostering employmentoriented rural projects. Highly capital-intensive plants for producing agricultural chemicals, which we can construct relatively well, may be a much better use for British aid. They may, indirectly, even generate more employment for the money spent. Such expertise as we have in directly employment-creating rural schemes should be used to help those countries that need it with demonstration projects. In general, the principle should surely be to use aid resources to complement those of countries which have well designed and reasonable programmes of rural development, whatever the aid is actually spent on. It should be specifically aimed at direct rural employment creation mainly where that is not the case. (There is the further problem too that rural employmentoriented schemes are likely to be relatively slowdisbursing; for several developing countries the requirement from the balance-of-payments point of view is much more to maintain a high rate of aid disbursements than to 'improve' the sectoral mix of aid use.)

On various other subjects what the White Paper has to say is more congenial. In fields such as health, urban development and housing, or education, aid has often supported investments that have actually fostered inequality. The recognition that this has been so, and attempts to avoid it in future, are surely welcome. As Florence Nightingale once said, the least you can ask of a hospital is that it "do the sick no harm". If, as Ashok Mitra suggests in his review, British aid does 'do harm' and contribute to an aggravation of inequality, it will either be because it has freed resources for investments which do have such effects, or because in general it supports govern- ments whose policies tend that way. This is asking us to believe that without British aid, the governments of those countries will behave better, or be replaced by others that do soan act of faith which I cannot share. I really think one must distinguish British from American aid policies, whose naked support of despicable governments, or disruption of relatively benign ones, has given aid a bad name. Britain abstained-and should have voted $\mathrm{No}-$ in the World Bank's recent decision to make a loan to Pinochet's Chile. But one can be sure that all the pressure to push this loan through came from the US Government. It was pressure which the World Bank should have resisted, even at the cost of displeasing Mr. Kissinger-it cannot fail to darken the Bank's reputation.

My real apprehensions about the White Paper, however, concern what it leaves out rather than what it says. Concentrating on aid, it gives a misleading picture of Britain's role in relation to the Third World in general. While I believe British aid is on the whole valuable to its recipients, in the totality of activities that affect Third World prosperity-or poverty--it bulks rather small. I do not mean just that the gross volume of aid has to be deflated first to its grant element (quite high in fact for current British aid) and then again by the costs of its other conditions - tying and so forth. Rather, that the role of Britain and British corporations in trade arrangements, international monetary reform, or private investment overseas is far more important than aid. One should not exaggerate: even in these fields Britain has a rather better record than many rich country governments; one of the functions of the Ministry of Overseas Development is to represent the interests of the Third World in Whitehall, and it does so with some success. It is doubtful, for example, that other EEC governments would have striven to give the Lomé Convention such positive features as it possesses without British initiatives, which owed a great deal to ODM and to Mrs. Hart in particular. British administrations have to cope with a more vocal Third World lobby than can be found in some other rich countries, and it frequently makes itself felt.

But look at what is missing from the White Paper: not a mention of multinational corporations, and the numerous ways research has shown them to benefit this country at the expense of the Third World. One would have thought there was beginning to be enough concern about the damage MNCs can do to the British economy to give them a place in ODM's thinking. There is quite a lot in the White Paper about new initiatives 
HMG has proposed or supported in the trade or monetary fields; but silence about all the things it has not supported, or where its support has been lukewarm. Those occasions-numerous occasions -when the British delegation did not insist on holding up international business in which Third World interests were at stake; those speeches saying 'much as we welcome this proposal in principle, the British government is not able to commit itself to supporting it in the immediate present; our own economic situation ...' I would like to see a White Paper on 'Britain's Economic Relations with the Third World', written jointly by the Foreign and Commonwealth Office, the
Department of Trade and Industry, and the Treasury. But I fear that if it were as frank as the truth demands, it would never be released for publication. As it is, the workings of British politics force us into all manner of unseemly compromises, the dictates of Anglo-American relations, the necessity of trade with South Africa. British interests! Perhaps we should regard it as a small victory for our better selves that there is an aid programme as well-intentioned as the one we have. But why didn't we oppose the World Bank's loan to Chile? I think we know why. 